UDC 541.128.13.547.264.

\title{
OXIDATIVE DEHYDROGENATION OF BUTYL ALCOHOLS TO THE CORRESPONDING CARBONYL COMPOUNDS OVER MODIFIED ZEOLITES
}

\author{
Z.A.Shabanova \\ Institute of Catalysis and Inorganic Chemistry, NAS of Azerbaijan \\ zumrud-042425-@mail.ru
}

Received 14.05.2021

Accepted 25.06.2021

\begin{abstract}
The catalytic properties of modified synthetic (A, X, Y) and natural (MOR, Clp) zeolites have been studied in the reactions of oxidative dehydrogenation of butyl alcohols to corresponding carbonyl compounds. It has been established that bimetallic zeolite catalysts show higher activity in these reactions.
\end{abstract}

Keywords: oxidative dehydrogenation, butyl alcohol, kinetics, mechanism.

doi

Due to the growth of alcoholic raw materials formed from wastes from the food and woodworking industries, the study of the oxidation processes of aliphatic alcohols creates objective prerequisites for the widespread use of these alcohols as raw materials for obtaining various valuable products. Metals $(\mathrm{Cu}, \mathrm{Ag}, \mathrm{Au}$, $\mathrm{Fe}$, Mo, etc.), transition metal oxides $(\mathrm{CuO}+$ $\mathrm{Cu}_{2} \mathrm{O}, \mathrm{V}_{2} \mathrm{O}_{5}, \mathrm{Cr}_{2} \mathrm{O}_{3}, \mathrm{MoO}_{3}$, etc.) are used as catalysts for the processes of heterogeneous catalytic oxidative dehydrogenation of aliphatic alcohols to the corresponding carbonyl compounds [1-4]. Over these contacts, the processes proceed at high temperatures with a relatively low selectivity for the target product.

Recently, natural and synthetic zeolites containing ion-exchange cations of transition metals $(\mathrm{Cu}, \mathrm{Pd}$, etc.) have been widely studied as catalysts for the partial oxidation of aliphatic alcohols to aldehydes [5-7].

The use of polyfunctional metal zeolite catalysts in these reactions leads to a reduction in the consumption of raw materials, to a decrease in operating costs for the isolation and purification of the resulting product, and to environmental protection.

This article summarizes the results of the selection of an active metal zeolite catalyst for the oxidative dehydrogenation (OD) reactions of butyl alcohols and the study of the kinetics of the reactions.

\section{Experimental part}

It has been investigated the catalytic activity of synthetic ( $\mathrm{NaA}, \mathrm{CaA}, \mathrm{NaX}, \mathrm{NaY})$ and natural zeolites - clinoptilolite (CLp) and mordenite (MOR) modified with cations of transition metals $(\mathrm{Cu}, \mathrm{Pd})$, in the reactions of oxidative dehydrogenation of butanol-1, butanol-2 and 2-methylpropanol-1.

The modification of zeolites with copper and palladium cations was carried out sequentially by the method of ion exchange in aqueous solutions of $\mathrm{CuC}_{12}$ and $\left[\mathrm{Pd}\left(\mathrm{NH}_{3}\right)_{4}\right] \mathrm{C}_{12}$. The amount of introduced cations was $0.5-5.0 \%$ for copper and $0.1-1.0 \%$ for palladium of the zeolite mass. Before ion exchange, natural zeolites were treated with $1 \mathrm{~N} \mathrm{HCl}$ solution. The amount of introduced cation was determined by ion spectral analysis on an Agilent 7700 ICP-MS.

The experiments were carried out in a flow apparatus with the quarts tube reactor connected directly to the gas chromatograph at atmospheric pressure in the temperature range $280-380^{\circ} \mathrm{C}$, molar ratios of reagents 1.00:(0.33-2.00):(1.33-4) and volumetric rates of the reaction mixture 1000-5000 h-1. Analysis of the starting reagents and reaction products was carried out by chromatography on an Agilent 7890 GC-MS.

A catalyst with a particle size of 0.23 $0.63 \mathrm{~mm}$ was loaded into the reactor in an amount of $3 \mathrm{~cm}^{3}$ and activated in a nitrogen flow at $400^{\circ} \mathrm{C}(3 \mathrm{~h})$, then the temperature was lowered to the reaction temperature and the reaction mixture was fed at a certain volumetric rate.

It was found that the transformation of alcohols on the studied catalysts occurs in the following directions: oxidative dehydrogenation; dehydration of alcohol; partial and deep oxidation. The yield of the reaction products is influenced by the porous structure of the zeolite, its 
physicochemical properties, as well as the nature and concentration of the cations introduced into the zeolites and the reaction conditions.

Studies of the catalytic activities of different types of zeolites in reactions of oxidative dehydrogenation of butyl alcohols have shown that the initial $\mathrm{Na}^{+}$- forms of zeolites exhibit low catalytic activity in comparison with their modified forms. The introduction of $\mathrm{Cu}^{2+}$ and $\mathrm{Pd}^{2+}$ cations into the composition of the zeolite leads to both an increase in the conversion of alcohol and an increase in the selectivity of the process with respect to the target product.

As a result of studying the catalytic activity of catalysts prepared on the basis of synthetic zeolites $\mathrm{NaA}$ and $\mathrm{CaA}$ containing different amounts of copper cations (0.5-5.0 wt\%), it was found that the optimal concentration of copper cations in terms of the yield of carbonyl compounds is $3.0 \mathrm{wt} \%$. \% for the $\mathrm{CuCaA}$ catalyst and 5.0 wt. \% for the CuNaA catalyst, and the $\mathrm{CuCaA}$ catalyst has a higher catalytic activity compared to the $\mathrm{CuNaA}$ catalyst (Table 1 ).

The introduction of palladium cations ( $0.1-$ $1.0 \mathrm{wt} \%$ ) into the composition of type A catalysts modified with copper cations leads to an increase in the activity of the catalyst. Introduction $0.1 \mathrm{wt}$. $\% \mathrm{Pd}^{2+}$ in the composition of the $\mathrm{CuCaA}$ catalyst $\left(3.0 \mathrm{wt} \% \mathrm{Cu}^{2+}\right)$ leads to an increase in the yield of 2 methyl propanal from 53.5 to $68.2 \%$, and with a further increase in the concentration of palladium ions to $1.0 \mathrm{wt}$. \% in the composition of the same catalyst under the same reaction conditions, the yield increases to $76.2 \%$. The same pattern is observed in the oxidative dehydrogenation of 1butanol and 2-butanol.

As a result of a comparative study of the catalytic activity of mono- and bimetallic zeolite catalysts prepared on the basis of synthetic zeolites

Table 1. Results of experiments on oxidative of butyl alcohols on modified zeolites at alcohol: $\mathrm{O}_{2}: \mathrm{N}_{2}=1.00: 0.33: 1.33$, $T=350^{0} \mathrm{C}, V=2000 \mathrm{~h}^{-1}$

\begin{tabular}{|c|c|c|c|c|c|c|c|c|}
\hline \multirow{2}{*}{ Zeolite } & \multirow{2}{*}{$\mathrm{Ca}^{2+}$} & \multirow{2}{*}{$\mathrm{Pd}^{2+}$} & \multicolumn{3}{|c|}{ Conversion of alcohol. $\%$} & \multicolumn{3}{|c|}{ The yield of reaction products. $\%$} \\
\hline & & & Butanol-1 & Butanol-2 & 2-Methyl propanol-1 & Butanal & Butanone & 2 methyl propanal \\
\hline \multirow[t]{7}{*}{ CLp } & \multicolumn{2}{|c|}{$\mathrm{Na}-$ form } & 13.1 & 11.1 & 19.9 & 7.5 & 3.4 & 13.3 \\
\hline & \multicolumn{2}{|c|}{$\mathrm{DA}-$ form } & 21.9 & 23.3 & 30.6 & 18.2 & 15.6 & 24.8 \\
\hline & - & 0.1 & 44.9 & 45.3 & 51.1 & 22.4 & 20.3 & 29.5 \\
\hline & 0.5 & 0.025 & 55.2 & 53.1 & 59.1 & 35.4 & 31.6 & 40.9 \\
\hline & 0.5 & 0.1 & 66.5 & 64.3 & 71.6 & 41.8 & 39.9 & 49.7 \\
\hline & 0.5 & 0.5 & 57.8 & 56.7 & 62.3 & 36.1 & 33.4 & 42.2 \\
\hline & 1.0 & 0.1 & 48.3 & 45.5 & 51.6 & 32.3 & 25.7 & 42.9 \\
\hline \multirow[t]{5}{*}{ MOR } & \multicolumn{2}{|c|}{ DA-form } & 29.1 & 26.6 & 33.8 & 11.5 & 5.6 & 24.3 \\
\hline & - & 0.1 & 42.2 & 38.1 & 45.1 & 13.3 & 5.9 & 25.3 \\
\hline & 0.5 & 0.1 & 57.7 & 53.3 & 60.6 & 25.9 & 6.3 & 36.9 \\
\hline & 0.1 & 0.1 & 58.4 & 54.9 & 62.4 & 20.7 & 18.7 & 32.3 \\
\hline & 2.0 & 0.1 & 52.3 & 49.9 & 56.4 & 19.6 & 16.6 & 30.1 \\
\hline \multirow[t]{7}{*}{$\mathrm{CaA}$} & - & - & 6.4 & 5.9 & 8.1 & 4.6 & 5.3 & 7.2 \\
\hline & 0.5 & - & 17.8 & 16.3 & 18.2 & 6.5 & 8.9 & 16.7 \\
\hline & 3.0 & - & 56.1 & 52.3 & 60.2 & 39.9 & 25.2 & 53.5 \\
\hline & 3.0 & - & 61.2 & 57.1 & 65.3 & 41.2 & 37.2 & 59.1 \\
\hline & 5.0 & - & 48.3 & 44.6 & 52.3 & 33.6 & 40.6 & 42.9 \\
\hline & 3 & 0.1 & 64.4 & 61.7 & 78.3 & 59.9 & 41.9 & 68.2 \\
\hline & 3 & 1.0 & 69.1 & 65.8 & 82.5 & 65.1 & 70.1 & 76.2 \\
\hline \multirow[t]{4}{*}{$\mathrm{NaA}$} & 3.0 & - & 37.4 & 35.6 & 52.1 & 30.8 & 25.1 & 41.4 \\
\hline & 5.0 & - & 49.1 & 44.1 & 60.1 & 38.6 & 33.2 & 49.6 \\
\hline & 5 & 0.1 & 56.9 & 61.9 & 78.9 & 42.6 & 39.9 & 59.2 \\
\hline & 5 & 1.0 & 60.3 & 65.2 & 80.1 & 45.8 & 42.2 & 62.5 \\
\hline \multirow[t]{3}{*}{$\mathrm{NaX}$} & 0.5 & 0.1 & 35.1 & 30.4 & 46.1 & 31.3 & 22.8 & 39.1 \\
\hline & 2.0 & 0.1 & 43.6 & 36.4 & 52.3 & 35.4 & 29.1 & 43.4 \\
\hline & 2.0 & 0.5 & 46.9 & 43.7 & 59.6 & 41.1 & 31.9 & 49.1 \\
\hline \multirow[t]{4}{*}{$\mathrm{NaY}$} & 0.5 & 0.1 & 37.2 & 32.1 & 49.1 & 31.9 & 25.2 & 42.1 \\
\hline & 2.0 & 0.1 & 40.6 & 38.4 & 54.1 & 38.7 & 30.5 & 48.9 \\
\hline & 3.0 & 0.1 & 38.2 & 36.6 & 53.7 & 36.4 & 28.8 & 46.4 \\
\hline & 2.0 & 0.5 & 46.3 & 42.2 & 61.1 & 28.3 & 29.3 & 32.6 \\
\hline
\end{tabular}


$\mathrm{NaX}$ and $\mathrm{NaY}$, it was found in the reactions studied that bimetal zeolite catalysts also exhibit higher catalytic activities in terms of the yield of target products, however, those prepared on the basis of $\mathrm{NaY}$ yield more higher than on samples prepared on the basis of $\mathrm{NaX}$. When studying the effect of the concentration of copper and palladium cations on the catalytic activity of $\mathrm{NaX}$ and $\mathrm{NaY}$ zeolites, the optimal concentration of these cations in terms of the yield of target products was established, which is 2.0 and $0.1 \mathrm{wt}$. \% respectively.

From the above results it follows that among the studied catalysts under the studied conditions, $\mathrm{CuPdCaA}$ with a content of $3.0 \mathrm{wt} . \%$ $\mathrm{Cu}^{2+}$ and 1.0 wt. $\% \mathrm{Pd}^{2+}$ exhibits the maximum catalytic activity and selectivity. The kinetic patterns of the reactions were studied using this sample.

Kinetic patterns were investigated at atmospheric pressure in the temperature ranges of $280-380^{\circ} \mathrm{C}$, volumetric velocities of $1000-4000$ $\mathrm{h}^{-1}$, at various partial pressures and in the absence of internal and external diffusion inhibition.

A stepwise mechanism was proposed for the reactions of partial oxidation of lower aliphatic alcohols on modified zeolite catalysts: (in the scheme, the zeolite matrix is represented by dashes, Bronsted acid centers $-\mathrm{H}^{+}$, metal cations $-\mathrm{Me}^{2+}$, nucleophilic oxygen $\left.-\mathrm{O}\right)[8,9]$ :

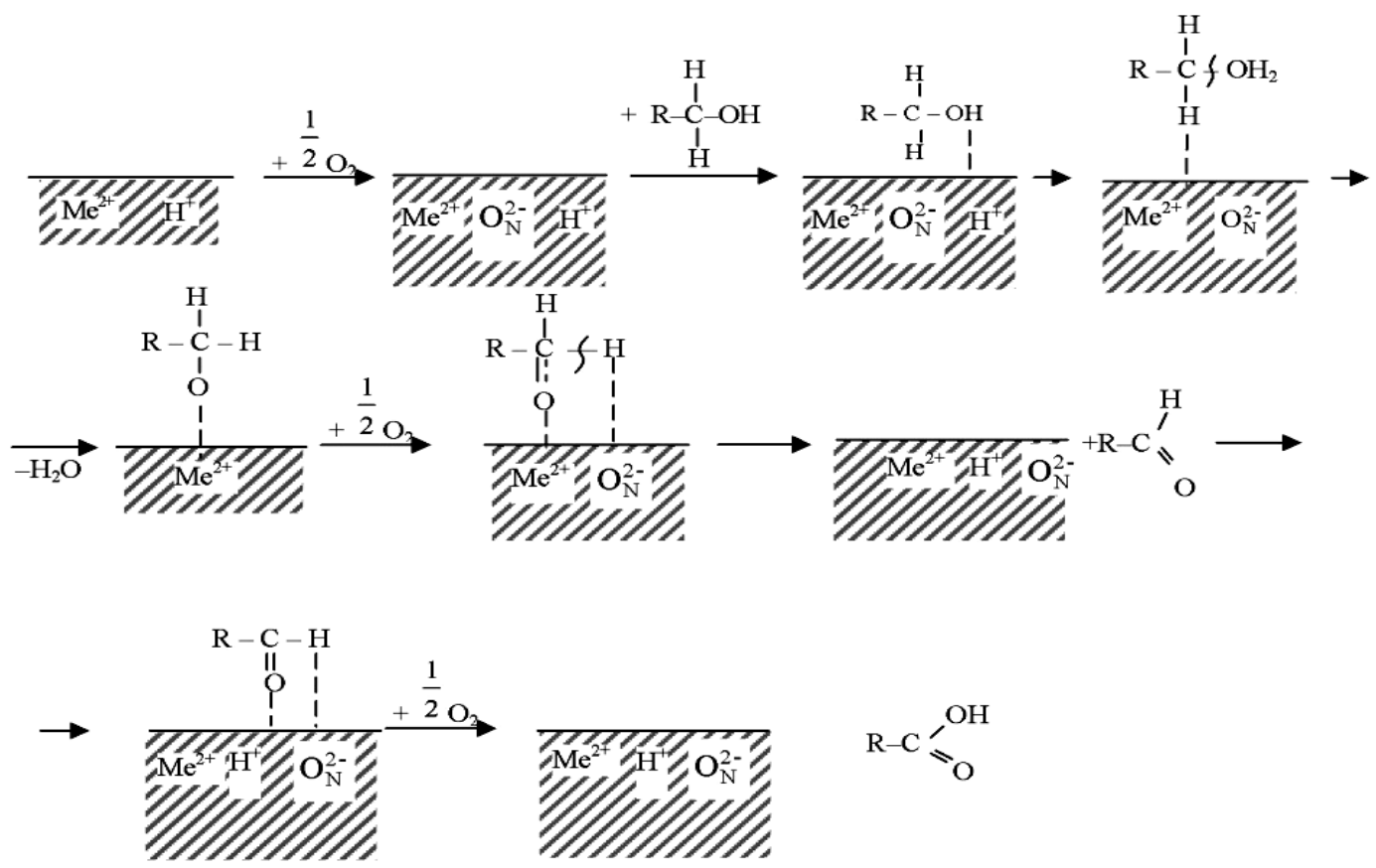

Assuming that the stages are elementary under the conditions of stationarity $r_{1}=r_{2}=r_{3}=$ $r_{4}$ and the constancy of the total number of surface regions $\sum \theta_{i}=1$, the equations for the rate of aldehyde or ketone formation obtained on the basis of the above mechanism are as follows [10]:

$$
r=k_{1} P_{\mathrm{O}_{2}}\left[\frac{\sqrt{1+4\left(\frac{k_{1} P_{\mathrm{O}_{2}}}{2 k_{2} P_{\mathrm{al}}}+\frac{k_{1} P_{\mathrm{O}_{2}}}{2 k_{3}}\right)-1}}{2\left(\frac{k_{1} P_{\mathrm{O}_{2}}}{2 k_{2} P_{\mathrm{al}}}+\frac{k_{1} P_{\mathrm{O}_{2}}}{2 k_{3}}\right)}\right]^{2}
$$

The numerical values of the constants of the kinetic equation calculated on the basis of experimental kinetic data are presented in Table 2.

Таблица 2. The numerical values of the constants of the kinetic equation

\begin{tabular}{|c|c|c|c|c|c|c|c|}
\hline \multicolumn{4}{|c|}{$\ln k_{i}^{0}$} & \multicolumn{4}{c|}{$E_{\mathrm{i}}$ ккал/моль } \\
\hline $\ln k_{1}^{0}$ & 16.5 & 7.19 & 28.024 & $E_{1}$ & 8.5 & 5.15 & 11.794 \\
\hline $\ln k_{2}^{0}$ & 13.9 & 4.03 & 7.869 & $E_{2}$ & 6.9 & 6.47 & 7.001 \\
\hline $\ln k_{3}^{0}$ & 15.9 & 7.67 & 24.169 & $E_{3}$ & 9.7 & 5.28 & 8.623 \\
\hline
\end{tabular}

With the numerical values of the constants of the kinetic equation given in Table 2, 
the relative errors of the experimental and calculated data did not exceed 7-12\%.

On the basis of the studies, it can be concluded that the proposed kinetic model in the studied range of variation of parameters describes the reaction mechanism well enough and can be used to develop a mathematical model of the process.

\section{Список литературы}

1. Cozzolino, M.; Tesser R., Di Serio M. et al. Kinetics of the oxidative dehydrogenation (ODH) of methanol to formaldehyde by supported vanadiumbased nanocatalysts. Catalysis Today. 2007. V. 128 (3-4). P. 191-200.

2. Braylovskiy S.M., Trofimova I.V., Temkin O.N. Vliyaniye prirody nositelya i kolichestva serebra na aktivnost' i selektivnost' katalizatora $\mathrm{v}$ reaktsiyakh prevrashcheniya metanola. Khim. Promyshlennost'. 1978. №7. S. 490-493.

3. Bagiyev V.A., Alkhazov T.G., Ukharskiy A., Matyshak V.A. Issledovaniye reaktsii okisleniya nizkomolekulyarnykh alifaticheskikh spirtov metodom IK-spektroskopii. Kinetika i kataliz. 1992. T. 33. № 3. S. 629-634

4. Allakhverdova N.Kh., Adzhamov K.Yu., Alkhazov T.G. Okisleniye alifaticheskikh spirtov $\left(\mathrm{S}_{1}-\mathrm{S}_{4}\right)$ na olovomolibdenovom katalizatore. Kinetika i kataliz. 1992. T. 33. № 2. S. 3-4.

5. Matiyev K.I., Aliyev A.M., Medzhidova S.M.
Sravneniye kataliticheskoy aktivnosti tseolitov A, $\mathrm{X}, \mathrm{Y}$, modifitsirovannykh kationami medi i palladiya, $\mathrm{v}$ reaktsii okisleniya izoamilovogo spirta. Azerb. neft. khoz-vo. 1996. № 6. S. 44-46.

6. Benjamin B., Manuel H., Neil G. H. Partial oxidation of ethanol on vanadia catalysts on supporting oxides with different redox properties compared to propanol. J. Catalysis. 2012. V. 296. P. 120-131.

7. Aliyev A.M., Tagiev D.B., Medzhidova S.M. Selective oxidation of propyl alcohols over zeolites modified with cations of the transitions metals . Zeolites and Mezoporous Materials of the down of the $21^{\text {st }}$ century. Proceedings of the $13^{\text {th }}$ Inter. Zeolite conf. France, Montpellier. 2001. P. 365.

8. Aliyev A.M., Shakhtakhtinsky T.N., Alikhanova Z.A. Vapor-phase oxidation of aliphatic alcohols over modified zeolite catalysts Vapor-phase oxidation of aliphatic alcohols over modified zeolite catalysts. World $6^{\text {th }}$ Congress on oxidation catalysis. Towards an integrated approach in innovation and development. Poster session A Lille - France. July 5-10. 2009. P. 110.

9. Aliyev A.M., Shabanova Z.A., Aliyev F.V. Oxidative dehydrogenation of hydrocarbons and the partialoxidation of aliphatic alcohols on modified zeolites. European Applied Sciences. 2015. No 5. P. 67-79.

10. Aliyev A.M., Shabanova Z.A., Aliyev F.V. Zeolites Modified Metal Cations as Catalysts in Hydrocarbon Oxidation and the Alkyl Alcohol. European Researcher. 2014. V. 82. № 9. P. 46-61.

\section{MODIFİKASIYYA OLUNMUŞ SEOLITLOR ÜZəRINDə BUTIL SPIRTLORININ UYĞUN KARBONILLİ

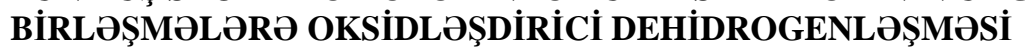

\section{Z.A.Şabanova}

Modifikasiya olunmuş sintetik (A, X, Y) və təbii (MOR, Clp) seolitlərin butil spirtlərinin uyğun karbonilli birləşmələrə oksidləşdirici dehidrogenləşməsi reaksiyalarında katalitik aktivliyi öyrənilmişdir. Müəyyən olunmuşdur ki, bimetalseolit katalizatorları bu reaksiyalarda yüksək aktivlik göstərir.

Açar sözlor: oksidlaşdirici dehidrogenlaşmə, butil spirti, kinetika, mexanizm.

\section{ОКИСЛИТЕЛЬНОЕ ДЕГИДРИРОВАНИЕ БУТИЛОВЫХ СПИРТОВ В СООТВЕТСТВУЮЩИЕ КАРБОНИЛЬНЫЕ СОЕДИНЕНИЯ НА МОДИФИЦИРОВАННЫХ ЦЕОЛИТАХ}

\section{3.А.Шабанова}

Каталитические свойства модифицированных синтетических (A, X, Y) и природных (MOR, Clp) цеолитов изучены в реакциях окислительного дегидрирования бутиловых спиртов в соответствующие карбонильные соединения. Установлено, что биметаллические цеолитные катализаторы проявляют более высокую активность в этих реакциях.

Ключевые слова: окислительное дегидрирование, бутиловый спирт, кинетика, механизм. 